\title{
FAKTOR-FAKTOR YANG MEMPENGARUHI PRODUKTIVITAS PABRIK BENIH PADI PT SANG HYANG SERI (PERSERO)
}

\author{
Sri Karuniari Nuswardhani ${ }^{1}$ ) \\ Bidjaksana Arief fateqah ${ }^{2}$ ) \\ 1). Staf pengajar Fakutas pertanian Universitas Yudharta Pasuruan \\ 2). Pegawai PT sang Hyang Seri (Persero) KR III
}

\begin{abstract}
ABSTRAK
PT Sang Hyang Seri (Persero) merupakan Badan Usaha Milik Negara (BUMN) yang bergerak dalam bidang perbenihan pertanian dituntut untuk menyiapkan benih secara 7 (tujuh) tepat untuk memenuhi kebutuhan konsumen (petani) dan laba yang optimal untuk kelangsungan hidup perusahaan. Oleh karena itu, produktivitas pabrik benih dalam memproduksi benih merupakan salah satu komponen penting dalam menunjang kesinambungan usaha.

Pada penelitian yang berjudul Faktor-faktor yang mempengaruhi Produktivitas pabrik benih padi PT Sang Hyang Seri (Persero) mempunyai tujuan untuk mengetahui rencana dan realisasi produksi benih padi masing-masing Kantor Regional (KR) PT SHS, untuk mengetahui perkembangan produktivitas masing-masing pabrik PT SHS dalam menghasilkan benih padi, dan untuk mengetahui faktor-faktor yang mempengaruhi produktivitas pabrik PT SHS dalam menghasilkan benih padi. Tujuan penelitian tersebut dicapai dengan mengumpulkan data sekunder, baik dari PT SHS maupun di luar perusahaan pada periode waktu 2010-2014 Data tersebut meliputi data produksi benih kantong, data pengadaan calon benih berupa gabah kering panen, data harga pembelian calon benih rata-rata per tahun, data kapasitas mesin terpasang , data jumlah alat dan mesin pengering (lantai jemur dan box dryer), data umur mesin (pabrik), dan data upah pengolahan benih yang kemudian dianalisis dengan cara tabulasi dan menggunakan bantuan program komputer SPSS dan EViews.

Dari hasil analisis menunjukkan bahwa realisasi produksi calon benih padi non hibrida (gkp) PT Sang Hyang Seri (Persero) dibandingkan dengan rencananya dalam kurun waktu lima tahun $(2010$ - 2014) tidak mencapai $100 \%$ di setiap tahunnya. Rata-rata realisasi produksi calon benih padi non hibrida (gkp) masing-masing Kantor Regional dan PBS pada tiap tahun dalam kurun waktu lima tahun $(2010$ - 2014) dibandingkan dengan rata-rata rencananya tidak mencapai 100\%. Realisasi produksi benih bersih padi non hibrida PT Sang Hyang Seri (Persero) dibandingkan dengan rencananya dalam kurun waktu lima tahun $(2010$ - 2014) tidak mencapai $100 \%$ pada setian tahunnya. Rata-rata realisasi produksi benih bersih padi non hibrida masingmasing Kantor Regional dan PBS pada tiap tahun selama waktu lima tahun (2010-2014) dibandingkan dengan rata-rata rencananya tidak mencapai $100 \%$.

Perkembangan (tren) produksi benih bersih padi non hibrida pada setiap kantor Regional dan PBS cenderung menurun, kecuali di Kantor Regional IV cenderung naik. Secara keseluruhan, perkembangan (tren) produksi benih bersih padi non hibrida PT Sang Hyang Seri (Persero) cenderung menurun. Pada produktivitas pabrik benih padi, perkembangan (tren) produktivitas pabrik benih padi pada setiap Kantor Regional dan PBS cenderung menurun, kecuali di Kantor Regional IV cenderung naik. Secara keseluruhan, perkembangan (tren) produktivitas pabrik benih padi PT Sang Hyang Seri (Persero) cenderung menurun.

Hasil estimasi menunjukkan bahwa secara bersama-sama variabel-variabel produksi calon benih padi, harga calon benih padi, jumlah box dryer, jumlah lantai jemur, umur pabrik (mesin), nrendemen benih, dan tenaga kerja berpengaruh nyata secara statistik terhadap
\end{abstract}


produktivitas pabrik benih padi. Namun, hasil estimasi secara individual terdapat 5 (lima) variable bebas yang memberi pengaruh signifikan secara statistik terhadap produktivitas pabrik benih padi pada $\alpha=1 \%$ dan $\alpha=10 \%$, yaitu produksi calon benih padi (gkp), jumlah box dryer, jumlah lantai jemur, rendemen benih, dan umur pabrik (mesin). Produksi calon benih padi (gkp) dan rendemen benih berpengaruh positif, sedangkan jumlah box dryer, jumlah lantai jemur, dan umur pabrik berpengaruh negatif.

Kata kunci : Produktivitas, PT Sang Hyang Seri (Persero), benih padi non hibrida

\section{PENDAHULUAN}

\section{A. Latar Belakang}

Sektor pertanian yang sangat menggantungkan pada kekayaan sumber daya alam merupakan sektor penting dalam perekonomian nasional. Hal ini karena sektor pertanian diharapkan mampu meningkatkan devisa negara dan mampu menjaga kelestarian sumber daya alam, sekaligus diharapkan mampu menyerap tenaga kerja.

Sebagai negara agraris, sebagian besar dari angkatan kerja dan kegiatan ekonomi nasional Indonesia berkutat di sekitar kegiatan sektor pertanian. Dengan demikian pembangunan sektor pertanian mempunyai peranan strategis dalam menjamin keamanan pangan penduduk.

Melalui program Revitalisasi Pertanian yang dicanangkan oleh Presiden RI pada tahun 2005, pemerintah telah berketetapan untuk menempatkan sektor pertanian sebagai penggerak pembangunan nasional, menempatkan pertanian sebagai sektor prioritas, yang didukung oleh sektor lainnya. Akselerasi pembangunan pertanian antara lain memerlukan dukungan sistem perbenihan yang baik. Keberhasilan pengembangan pangan sangat ditentukan oleh ketersediaan benih dalam jumlah, kualitas, waktu dan harga yang tepat. Pemerintah telah memberikan perhatian serius terhadap perbenihan dan pembibitan baik yang berkaitan dengan sistem pengembangannya, penangkaran, distribusi, pembinaan, sistem cadangan, dan mekanisme pengadaannya termasuk subsidi.

Pemerintah mendorong pengembangan industri perbenihan, karena selain memperkuat mata rantai sistem pertanian juga memperkuat sistem agribisnis yang menjanjikan keuntungan yang cukup besar. Di beberapa negara peranan seed industry mencapai lebih dari $25 \%$ dari total PDB yang dihasilkan oleh sektor pertanian (Nuswardhani, 2011).

Penggunaan benih unggul berlabel di Indonesia masih terbatas. Oleh karena itu, Pemerintah selalu mendorong petani untuk meningkatkan penggunaan benih unggul 
berlabel, baik melalui program bantuan benih maupun swadaya petani. Sejalan dengan upaya peningkatan penggunaan benih unggul berlabel, maka industri benih (pemasok benih) juga harus meningkatkan kemampuannya dalam memproduksi benih. Untuk meningkatkan produksi dan produktivitas benih yang cukup dan memadai diperlukan usaha antara lain :

a. Penyediaan dan penggunaan benih sumber yang unggul dan berkualitas

b. Ketersediaan Sumber Daya Manusia yang memadai

c. Sistem perbenihan, termasuk Industri benih yang mapan

d. Institusi penunjang perbenihan

e. Dukungan dari Pemerintah.

Berdasarkan kemampuan produksinya, industri benih dapat dikelompokkan dalam skala kecil dan skala besar. Berdasarkan statusnya, industri benih dapat berupa swasta, pemerintah, dan BUMN.

PT Sang Hyang Seri (Persero) disingkat PT SHS (Persero) merupakan badan Usaha Milik Negara (BUMN) yang mempunyai tugas pokok untuk memproduksi dan memasarkan benih tanaman pangan. Dalam memproduksi dan memasarkan benih tersebut, PT Sang Hyang Seri (Persero) setiap tahun menyusun
Rencana Kerja. Rencana Kerja tersebut dijabarkan pada setiap Cabang dalam lingkungan Kantor Regional masing-masing. Terdapat 6 (enam) Kantor Regional (KR) di lingkungan PT Sang Hyang Seri (Persero) seluruh Indonesia, Yaitu Kantor Regional I, yang berpusat di Sukamandi, Kantor Regional II di Klaten, Kantor Regional III di Malang, Kantor Regional IV di Medan, Kantor Regional V di Lampung, dan Kantor Regional VI di Sulawesi Selatan. Setiap Kantor Regional terdiri dari beberapa cabang yang menyebar di seputar daerah/wilayah Kantor Regional tersebut.

Pada setiap Cabang memiliki pabrik untuk memproduksi benih untuk dipasarkan. Jumlah, jenis, dan kapan benih diproduksi mengikuti perencanaan pemasaran. Keakuratan penyediaan benih untuk memenuhi kebutuhan pemasaran sangat dipengaruhi oleh faktor internal dan faktor eksternal. Faktor internal berasal dari dalam lingkungan pabrik sendiri, antara lain adalah jumlah, kapasitas dan umur mesin. Faktor eksternal berasal dari luar pabrik, antara lain adalah jumlah dan mutu bahan baku (calon benih). Berdasarkan pada pengaruh faktor internal dan faktor eksternal tersebut yang dapat berbeda-beda pada setiap pabrik, maka produktivitas pabrik dapat berbeda-beda pula dalam menghasilkan benih. 
PT Sang Hyang Seri (Persero) dalam kinerjanya dituntut untuk menyiapkan benih secara 7 (tujuh) tepat untuk memenuhi kebutuhan konsumen (petani), dan laba yang optimal untuk kelangsungan hidup perusahaan. Sedangkan 7 (tujuh) tepat tersebut yaitu tepat mutu, tepat waktu, tepat jumlah, tepat varietas, tepat harga, tepat tempat, dan tepat layanan.

Dewasa ini masalah produktivitas telah menjadi pembicaraan banyak orang. Oleh karena itu masalah produktivitas merupakan suatu masalah yang sangat penting, dan erat kaitannya dengan perkembangan kemajuan perusahaan.

Tingkat keberhasilan suatu perusahaan dapat diukur berdasarkan atas profit atau keuntungan yang diperoleh dalam periode waktu tertentu dan itu bisa dilihat dari produk yang dikeluarkan oleh perusahaan. Namun profit ini tidak dapat tercapai tanpa manajemen yang mengaturnya, dalam hal ini manajemen finansial yang secara ketat mengaturnya. Peningkatan profit dapat disebabkan oleh adanya produktivitas yang tinggi di dalam perusahaan itu. Produktivitas yang tinggi akan berakibat luas bagi perusahaan, diantaranya penghematan biayabiaya yang terjadi dalam operasi perusahaan sehari-hari. Dengan adanya penghematan biaya tersebut maka berakibat pada peningkatan profit usaha.

Produktivitas merupakan indikator yang utama bagi kemajuan perekonomian negara, sehingga peningkatan produktivitas pada semua sektor merupakan suatu cara untuk meningkatkan laju pertumbuhan ekonomi. Akan tetapi peningkatan produktivitas dipengaruhi oleh kenaikan profitabilitas. Landasan untuk meningkatkan produktivitas dan profitabilitas perusahaan adalah membangun suatu sistem yang memperhatikan secara terfokus dan bersama-sama pada aspek kualitas, efektivitas pencapaian tujuan, dan efisiensi penggunaan sumber-sumber daya. Selanjutnya indikator keberhasilan itu dapat dipantau melalui pengukuran produktivitas dan profitabilitas secara terus-menerus. Pengukuran produktivitas memberikan informasi tentang masalah-masalah internal dari perusahaan, sedangkan profitabilitas memberikan informasi tentang masalahmasalah eksternal dari perusahaan.

Pada tingkat perusahaan, pengukuran produktivitas terutama digunakan sebagai sarana manajemen untuk menganalisis dan mendorong efisiensi produksi. Suatu organisasi perusahaan perlu mengetahui pada tingkat produktivitas mana perusahaan itu beroperasi, agar dapat 
membandingkannya dengan produktivitas standar yang telah ditetapkan manajemen, mengukur tingkat perbaikan produktivitas dari waktu ke waktu, dan membandingkan dengan produktivitas industri sejenis yang menghasilkan produk/ jasa serupa. Hal ini menjadi penting agar perusahaan ini dapat meningkatkan daya saing dari produk/ jasa yang dihasilkannya di pasar global yang sangat kompetitif (Rahmawati, 2006)

Peningkatan produktivitas dapat diupayakan melalui peningkatan efisiensi penggunaan bahan-bahan masuk (input) yang dipakai untuk dapat menghasilkan keluaran (output) atau dengan kata lain meningkatkan output yang dihasilkan serta menekan input yang digunakan untuk dapat menghasilkan output tersebut. Produktivitas dapat diupayakan dengan menghasilkan produk-produk yang sebesar-besarnya dari sumber daya yang sekecil-kecilnya. Oleh karena itu sangat penting kiranya suatu perusahaan mengenal faktor-faktor yang mempengaruhi produktivitas dan seberapa besar faktor internal dan faktor eksternal dapat mempengaruhi produktivitas pabrik akan dianalisis dalam penelitian ini agar peningkatan yang diupayakan dapat terjadi secara optimal. Di samping itu, penelitian ini juga akan mengidentifikasi faktor-faktor apa saja yang dapat mempengaruhi produktivitas pabrik di luar yang telah disebutkan di atas. Untuk selanjutnya diupayakan perbaikan produktivitas secara terus menerus.

\section{B. Perumusan Masalah}

Dalam sistem pengukuran kinerja perusahaan, terdapat tujuh tolok ukur yang diperhatikan, yaitu efektivitas, efisiensi, kualitas, profitabilitas, produktivitas, quality of work life, dan inovasi (Sink,1985). Perusahaan kadang-kadang kurang memperhatikan efisiensi penggunaan sumber daya (input) yang dimiliki dengan hanya melihat tingkat profit yang dicapainya pada periode tertentu, sehingga mengeluarkan biaya yang besar untuk melaksanakan aktivitas sehari-hari (termasuk proses produksi) yang berpengaruh pada penerimaan profit perusahaan. Jika biaya yang dikeluarkan semakin besar maka profit yang diterima semakin kecil.

Analisis yang dilakukan terhadap produktivitas perusahaan merupakan cara yang efektif untuk mendasari perencanaan yang lebih realistis dan sebagai penentu strategi perusahaan. Pengukuran produktivitas yang dilakukan secara berkala dan terus menerus akan memberikan informasi pola pertumbuhan perusahaan pada suatu periode yang kemudian dapat diimplementasikan pada periode mendatang. 
Produktivitas berkaitan dengan efisiensi penggunaan input dalam memproduksi output. Dengan mengetahui tingkat produktivitasnya, maka suatu perusahaan akan mampu bersaing dengan perusahaan lain yang sejenis. Pengukuran produktivitas selain dapat untuk mengetahui tingkat kinerja perusahaan secara keseluruhan juga dapat dijadikan sebagai pedoman untuk melakukan perbaikan secara kontinyu (continual improvement).

Produktivitas dapat diukur dengan membandingkan output dengan input dari proses produksi. Output adalah produk yang dihasilkan, sedangkan input adalah sumber daya (resources) yang digunakan dalam proses produksi. Tinggi rendahnya suatu produktivitas berkaitan dengan efisiensi dari sumber-sumber daya (input) dalam menghasilkan suatu produk atau jasa (output).

Pabrik-pabrik yang ada di Cabangcabang di Kantor Regional PT Sang Hyang Seri (Persero) akan mengolah calon benih benih yang telah lulus seleksi lapangan menjadi benih kantong yang siap dijual oleh bagian pemasaran. Selama proses pengolahan, calon benih tersebut mengalami berbagai perlakuan yaitu pengeringan, pembersihan, sortasi, penyusunan lot benih bersih, penyimpanan benih lulus, dan pengemasan (benih kantong) sebelum pada akhirnya dijual. Dari proses pengeringan sampai menjadi benih kantong, calon benih/benih tersebut mengalami penyusutan berat, karena terjadi penurunan kadar air dan mengalami penyusutan volume karena pembersihan dan sortasi. Dengan demikian, proses pengolahan benih ini menghasilkan biji sebagai benih dan biji bukan kategori benih (hasil samping). Proses tersebut berjalan dengan bantuan mesin, tenaga kerja manusia, dan peralatan yang lain. Input yang diproses dalam hal ini calon benih akan menjadi output dalam hal ini benih bersih. Perbandingan antara output (benih bersih) dengan input (calon benih) disebut dengan rendemen benih.

Pabrik-pabrik pengolahan benih di tiap cabang beroperasi menghasilkan benih sepanjang tahun, sesuai dengan target penjualan cabang yang penentuannya antara lain berdasarkan kapasitas pabrik. Produksi benih pada cabang yang bersangkutan dapat tidaknya mencukupi kebutuhan pemasaran, antara lain sangat bergantung pada jumlah dan mutu calon benih, kondisi dan kapasitas mesin. Perbandingan antara produksi benih kantong aktual yang diolah sendiri dengan kapasitas pabrik terpasang disebut sebagai produktivitas pabrik. 
Berdasarkan pada uraian di atas, maka perumusan masalah dalam penelitian ini adalah sebagai berikut :

a. Bagaimanakah rencana dan realisasi produksi benih masing-masing Kantor Regional PT SHS.

b. Berapa tingkat produktivitas pabrik tiap Kantor Regional dengan melakukan pengukuran produktivitas.

c. Apa sajakah faktor-faktor yang mempengaruhi produktivitas pabrik.

\section{Tujuan}

a. Untuk mengetahui rencana dan realisasi produksi benih padi masing-masing Kantor Regional PT SHS.

b. Untuk mengetahui perkembangan produktivitas masing-masing pabrik PT SHS dalam menghasilkan benih padi.

c. Untuk mengetahui faktor-faktor yang mempengaruhi produktivitas pabrik PT SHS dalam menghasilkan benih padi.

\section{METODE PENELITIAN}

1. Ruang Lingkup

\section{Produksi benih PT Sang} Hyang Seri (Persero) meliputi benih padi non hibrida, benih padi hibrida, benih jagung (komposit dan hibrida), benih kedelai dan benih sayuran atau hortikultura. Namun dalam penelitian yang berjudul Faktor-Faktor yang Mempengaruhi Produktivitas Pabrik di PT Sang Hyang Seri (Persero) hanya mencakup produksi benih padi non hibrida dengan pertimbangan bahwa lokasi yang diteliti semuanya memproduksi benih padi non hibrida, sehingga datanya cukup tersedia. Produksi benih padi non hibrida yang diteliti adalah proses mulai dari pemasukan calon benih berupa gabah kering panen yang dihasilkan dari areal penangkaran sendiri (kerja sama) sampai menjadi benih bersih. Benih bersih tersebut diasumsikan menjadi benih kantong semua.

\section{Lokasi dan Waktu Penelitian}

Dengan mempertimbangkan bahwa semua lokasi penelitian memproduksi benih padi non hibrida dan agar hasil penelitian dapat menggambarkan kondisi yang 
sebenarnya, maka lokasi yang diteliti adalah semua Kantor Regional yang dimiliki PT Sang Hyang Seri (Persero) yang berjumlah enam buah ditambah Pusat Benih Sumber (PBS). Jangka waktu penelitian dilaksanakan dalam 2 (dua) bulan dimulai dari Januari sampai dengan Februari 2015.

\section{B. Metode Pengumpulan Data}

\section{Macam dan Sumber Data}

Penelitian ini memanfaatkan data sekunder yang dimiliki PT Sang Hyang Seri (Persero) yang terdiri dari data produksi benih kantong, data pengadaan calon benih berupa gabah kering panen, data harga pembelian calon benih rata-rata per tahun, data kapasitas mesin terpasang, data jumlah alat dan mesin pengering (lantai jemur dan box dryer), data umur mesin (pabrik), dan data tenaga kerja pengolahan benih. Data

produksi benih kantong yang digunakan berasal dari produksi sendiri yang didekati dari produksi benih bersih. Jadi, diasumsikan bahwa benih bersih semuanya dapat menjadi benih kantong. Data yang diambil merupakan data deret waktu (time series) selama lima tahun mulai tahun 2010 sampai dengan tahun 2014.

Sumber data berasal dari laporan tahunan dan arsip setiap Kantor Regional, baik yang ada di Kantor Regional masing-masing maupun yang berada di Kantor Pusat. Sumber data yang lain berasal dari pustaka (hasil penelitian, jurnal, dan lain-lain) dan internet yang mendukung penelitian ini.

\section{Teknik Pengumpulan Data}


a. Observasi langsung, adalah pengumpulan data dengan mengadakan

pengamatan secara logis terhadap objek yang akan diteliti.

b. Pencatatan, adalah pengumpulan data dengan cara mengutip dari buku, laporan dan dokumen PT Sang Hyang Seri (Persero).

c. Wawancara, adalah pengumpulan informasi dengan cara meminta keterangan kepada nara sumber untuk memperjelas data yang membutuhkan keterangan lebih lanjut.

\section{Metode Analisis Data}

1. Untuk membandingkan realisasi produksi masing-masing Kantor Regional dianalisis dengan menggunakan analisis tabel. Realisasi produksi masing-masing Kantor
Regional, kemudian diperbandingkan satu dengan lainnya.

2. Untuk mengetahui perkembangan produktivitas masing-masing pabrik di Kantor Regional dianalisis dengan menghitung pertumbuhan produktivitas selama 5 tahun terakhir. Produktivitas pabrik dihitung dengan melihat rasio antara produksi dengan kapasitas terpasang.

3. Untuk mengetahui faktor-faktor yang mempengaruhi produktivitas pabrik dianalisis dengan menggunakan model regresi linier berganda. Taksiran persamaan regresi berganda ditulis dalam bentuk logaritma sebagai berikut :

$\ln$ PROVITAS $=b_{0}+b_{1} \operatorname{lnGKP}+b_{2}$ $\ln \mathrm{HGKP}+\mathrm{b}_{3} \ln \mathrm{KPBR}+\mathrm{b}_{4} \ln$ BDRYER + $b_{5} \ln$ LJEMUR + $\mathrm{b}_{6} \ln \mathrm{UPBR}+\mathrm{b}_{7} \ln \mathrm{TKERJA}$

dengan :

PROVITAS : Produktivitas pabrik (produksi benih kantong dibagi kapasitas mesin terpasang) 
GKP : Gabah kering panen yang diolah

HGKP : Harga gabah kering panen yang diolah

KPBR : $\quad$ Kapasitas pabrik

BDRYER : Jumlah box dryer $\quad$ JKEMUR : Jumlah lantai jemur

UPBR : $\quad$ Umur pabrik (mesin)

TKERJA : Tenaga kerja yang terlibat langsung dalam pengolahan benih

$\mathrm{b}_{0} \quad$ : Konstanta

$b_{1} \ldots b_{7}: \quad$ Koefisien parameter

regresi masing-masing variabel

\section{Pengujian Hipotesis}

Pengujian hipotesis dimaksudkan untuk menguji pengaruh variabel bebas terhadap variabel tidak bebas. Uji ini meliputi uji F dan uji t.

\section{Uji F (F test)}

\section{Uji F atau overall test} merupakan uji signifikansi simultan yang pada dasarnya menunjukkan apakah semua variabel independen yang dimasukkan dalam model mempunyai pengaruh secara serentak terhadap variabel dependen. Hipotesis nol (Ho) yang hendak diuji apakah semua parameter dalam model penelitian ini sama dengan nol, atau: $\mathrm{H}_{0}: \mathrm{b}_{1}, \mathrm{~b}_{2}, \mathrm{~b}_{3}, \mathrm{~b}_{4}, \mathrm{~b}_{5}, \mathrm{~b}_{6}$ dan $\mathrm{b}_{7}=0$. Artinya, semua variabel independen bukan merupakan penjelas yang signifikan terhadap variabel dependen. Hipotesis alternatif $\quad\left(\mathrm{H}_{1}\right), \quad$ tidak semua parameter penelitian ini secara simultan sama dengan nol, atau:

$\mathrm{H}_{1}: \mathrm{b}_{1}, \mathrm{~b}_{2}, \mathrm{~b}_{3}, \mathrm{~b}_{4}, \mathrm{~b}_{5}, \mathrm{~b}_{6}$ dan $\mathrm{b}_{7} \neq 0$. Artinya, semua variabel independen secara simultan merupakan penjelas yang signifikan terhadap variabel dependen.

\section{Uji t ( t test)}

Uji t merupakan uji signifikansi parameter individual yang pada dasarnya menunjukkan seberapa jauh pengaruh variabel independen secara individual dalam menerangkan variasi variabel dependen. Hipotesis nol $\left(\mathrm{H}_{0}\right)$ yang hendak diuji apakah parameter 
penelitian ini $\left(b_{1}, b_{2}, b_{3}, b_{4}, b_{5}, b_{6}\right.$ dan

$\mathrm{b}_{7}$ ) sama dengan nol, atau:

$\mathrm{H}_{0}: \mathrm{b}_{1}, \mathrm{~b}_{2}, \mathrm{~b}_{3}, \mathrm{~b}_{4}, \mathrm{~b}_{5}, \mathrm{~b}_{6}$ dan $\mathrm{b}_{7}=0$.

Artinya, variabel-variabel

eksplanatori bukan merupakan

penjelas yang signifikan terhadap

variabel produktivitas pabrik benih

padi non hibrida. Hipotesis alternatif

$\left(\mathrm{H}_{1}\right)$, parameter penelitian ini ini $\left(\mathrm{b}_{1}\right.$,

$b_{2}, b_{3}, b_{4}, b_{5}, b_{6}$ dan $b_{7}$ ) tidak sama

dengan nol, atau:

$H_{1}: b_{1}, b_{2}, b_{3}, b_{4}, b_{5}, b_{6}$ dan $b_{7} \neq 0$.

Artinya, variabel-variabel

eksplanatori merupakan penjelas

yang signifikan terhadap variabel

produktivitas pabrik benih padi non

hibrida.

Nilai $\mathrm{t}$ tabel yang diperoleh

dibandingkan nilai $\mathrm{t}_{\text {hitung, }}$ apabila $\mathrm{t}$

hitung lebih besar dari $t_{\text {tabel }}$, maka Ho

ditolak, sehingga dapat disimpulkan

bahwa variabel independen

berpengaruh pada variabel dependen.
Apabila $\mathrm{t}_{\text {hitung }}$ lebih kecil dari $\mathrm{t}_{\text {tabel, }}$,

maka Ho diterima sehingga dapat

disimpulkan bahwa variabel

independen tidak berpengaruh

terhadap variabel dependen.

\section{E. Definisi dan Pengukuran Variabel}

1. Produktivitas yaitu hasil dari proses pengolahan calon benih berupa gabah kering panen yang menjadi benih kantong dibagi dengan kapasitas terpasang pabrik.

2. Benih kantong yaitu benih lulus yang sudah dikemas dan siap untuk disalurkan (ton).

3. Produksi benih lulus yaitu benih bersih yang sudah lulus pengujian laboratorium dari Balai Pengawasan dan Sertifikasi Benih atau sertifikasi mandiri (ton).

4. Gabah kering panen yaitu hasil panen calon benih padi non hibrida yang sudah dinyatakan lulus sertifikasi lapangan oleh Balai Pengawasan dan 
Sertifikasi Benih atau sertifikasi mandiri (ton).

5. Harga gabah kering panen yaitu realisasi harga rata-rata tahunan pengadaan gabah kering panen (calon benih) (Rp/ton).

6. Kapasitas pabrik yaitu potensi kemampuan pabrik untuk menghasilkan benih dalam satu tahun (ton/tahun).

7. Box dryer yaitu mesin pengering calon benih (gabah kering panen) yang menggunakan minyak bakar (unit).

8. Lantai jemur yaitu alat pengering calon benih (gabah kering panen) yang menggunakan panas sinar matahari (unit).

9. Umur pabrik (mesin) yaitu lama pabrik (mesin) beroperasi dihitung mulai dari awal beroperasi sampai dengan waktu pelaksanaan penelitian (tahun).
10. Rendemen benih yaitu rasio (persentase) jumlah benih bersih yang dihasilkan dari gabah kering panen (calon benih) yang diolah (\%).

11. Tenaga kerja yaitu jumlah tenaga kerja organik yang menangani langsung proses pengolahan benih (orang).

\section{HASIL DAN PEMBAHASAN}

\section{A. Produksi Benih}

Proses pengolahan benih padi diawali dengan pemasukkan atau pengadaan calon benih padi berupa gabah kering panen (gkp). Mutu gkp yang masuk harus memenuhi persyaratan kadar air maksimal $25 \%$ dan kadar kotoran maksimal $7 \%$.

Pengadaan gkp dalam kurun waktu lima tahun (2010-2014) di PT SHS secara keseluruhan terdapat kecenderungan menurun. Hal ini dapat dilihat pada reratanya 
sebagaimana tercantum pada tabel

1. Pada tahun 2010, produksi gkp

sebanyak $12,076.41$ ton sementara

pada tahun 2014 turun menjadi

$11,555.56$ ton.

Penurunan produksi gkp

dapat berakibat pada penurunan

produktivitas pabrik, karena

kapasitas pabrik tidak dapat dioptimalkan. Penurunan produksi gkp ini juga dapat mengakibatkan peningkatan pengadaan benih dari pihak ketiga untuk memenuhi target produksi. Sebagaimana tampak pada tabel 1. bahwa rata-rata realisasi pengadaan gkp tiap tahun selalu tidak dapat memenuhi rencananya.

Tabel 1. Rencana dan Realisasi Produksi Calon Benih Padi (GKP) dan Reratanya per KR Selama Lima Tahun (2010-2014)

\begin{tabular}{|c|c|c|c|c|c|c|c|c|c|c|}
\hline No & & Tahun & KRI & KR II & KR III & KR IV & KRV & KR VI & PBS & RERATA \\
\hline \multirow[t]{3}{*}{1} & 2010 & Rencana & $27,152.32$ & $19,602.15$ & $9,933.77$ & $8,610.00$ & $9,273.00$ & $9,273.00$ & 927.50 & $12,110.25$ \\
\hline & & Realisasi & $30,722.03$ & $18,227.86$ & $11,313.68$ & $9,966.15$ & $6,637.00$ & $6,636.92$ & $1,031.30$ & $12,076.42$ \\
\hline & & $\%$ & 113.15 & 92.99 & 113.89 & 115.75 & 71.57 & 71.57 & 111.19 & 99.72 \\
\hline \multirow[t]{3}{*}{2} & 2011 & Rencana & $35,562.91$ & $19,605.15$ & $9,933.77$ & $8,610.00$ & $9,273.00$ & $9,273.00$ & 927.50 & $13,312.19$ \\
\hline & & Realisasi & $28,893.30$ & $14,381.82$ & $7,702.85$ & $8,252.06$ & $10,482.06$ & $10,482.92$ & $1,020.07$ & $11,602.16$ \\
\hline & & $\%$ & 81.25 & 73.36 & 77.54 & 95.84 & 113.04 & 113.05 & 109.98 & 87.15 \\
\hline \multirow[t]{3}{*}{3} & 2012 & Rencana & $28,733.38$ & $28,008.99$ & $13,924.30$ & $11,410.60$ & $11,457.00$ & $14,635.76$ & 925.00 & $15,585.00$ \\
\hline & & Realisasi & $35,612.08$ & $1,774.49$ & $8,414.76$ & $11,349.18$ & $4,618.56$ & $6,787.67$ & 990.12 & $9,935.26$ \\
\hline & & $\%$ & 123.94 & 6.34 & 60.43 & 99.46 & 40.31 & 46.38 & 107.04 & 63.75 \\
\hline \multirow[t]{3}{*}{4} & 2013 & Rencana & $37,335.00$ & $22,665.00$ & $16,010.00$ & $16,935.00$ & $12,935.00$ & $12,265.00$ & 949.00 & $17,013.43$ \\
\hline & & Realisasi & $32,313.32$ & $12,532.36$ & $10,704.13$ & $16,005.96$ & $5,498.87$ & $4,287.54$ & 845.02 & $11,741.03$ \\
\hline & & $\%$ & 86.55 & 55.29 & 66.86 & 94.51 & 42.51 & 34.96 & 89.04 & 69.01 \\
\hline \multirow[t]{3}{*}{5} & 2014 & Rencana & $38,342.00$ & $23,330.00$ & $16,675.00$ & $17,600.00$ & $13,600.00$ & $12,930.00$ & $1,000.00$ & $17,639.57$ \\
\hline & & Realisasi & $28,668.59$ & $14,147.43$ & $8,905.30$ & $15,724.22$ & $7,310.00$ & $5,480.95$ & 652.41 & $11,555.56$ \\
\hline & & $\%$ & 74.77 & 60.64 & 53.41 & 89.34 & 53.75 & 42.39 & 65.24 & 65.51 \\
\hline & RERATA & A Rencana & $33,425.12$ & $22,642.26$ & $13,295.37$ & $12,633.12$ & $11,307.60$ & $11,675.35$ & 945.80 & $15,132.09$ \\
\hline & & Realisasi & $31,241.86$ & $12,212.79$ & $9,408.14$ & $12,259.51$ & $6,909.30$ & $6,735.20$ & 907.78 & $11,382.08$ \\
\hline & & $\%$ & 93.47 & 53.94 & 70.76 & 97.04 & 61.10 & 57.69 & 95.98 & 75.22 \\
\hline
\end{tabular}

Sumber : Data sekunder PT SHS, diolah 
Dengan adanya kecenderungan

penurunan produksi gkp, maka

produksi benih bersih padi (BB)

juga cenderung menurun.

Sebagaimana tampak pada tabel 2,

bahwa rerata produksi benih bersih

padi pada tahun 2010 sebanyak

9,186.10 ton, tetapi pada tahun 2014

turun menjadi sebanyak $8,788.58$ ton. Dalam kurun waktu lima tahun

tersebut, rata-rata realisasi produksi

benih bersih padi tidak pernah mencapai angka $100 \%$ terhadap

rencananya. Benih bersih padi yang

diproduksi tersebut diasumsikan

semuanya dapat menjadi benih

kantong untuk memudahkan

analisis.

Tabel 2. Rencana dan Realisasi Produksi Benih Bersih Padi (BB) dan Reratanya per KR Selama Lima Tahun (2010-2014)

\begin{tabular}{|c|c|c|c|c|c|c|c|c|c|c|}
\hline No & & Tahun & KRI & KR II & KR III & KRIV & KRV & KR VI & PBS & RERATA \\
\hline \multirow[t]{3}{*}{1} & 2010 & Rencana & $20,500.00$ & $20,300.00$ & $8,592.09$ & $7,500.00$ & $7,000.00$ & $7,000.00$ & 700.00 & $10,227.44$ \\
\hline & & Realisasi & $23,691.19$ & $13,659.73$ & $8,592.09$ & $7,560.44$ & $5,009.00$ & $5,008.68$ & 781.55 & $9,186.10$ \\
\hline & & $\%$ & 115.57 & 67.29 & 100.00 & 100.81 & 71.56 & 71.55 & 111.65 & 89.82 \\
\hline \multirow[t]{3}{*}{2} & 2011 & Rencana & $26,850.00$ & $20,300.00$ & $9,500.00$ & $7,500.00$ & $7,000.00$ & $7,000.00$ & 700.00 & $11,264.29$ \\
\hline & & Realisasi & $22,036.87$ & $10,863.34$ & $5,509.50$ & $6,169.24$ & $7,994.02$ & $7,918.02$ & 776.77 & $8,752.53$ \\
\hline & & $\%$ & 82.07 & 53.51 & 57.99 & 82.26 & 114.20 & 113.11 & 110.97 & 77.70 \\
\hline \multirow[t]{3}{*}{3} & 2012 & Rencana & $24,820.00$ & $14,825.00$ & $19,055.00$ & $12,800.00$ & $11,250.00$ & $11,550.00$ & 700.00 & $13,571.43$ \\
\hline & & Realisasi & $25,947.17$ & $1,272.26$ & $6,172.91$ & $8,599.07$ & $3,487.26$ & $5,128.89$ & 737.13 & $7,334.95$ \\
\hline & & $\%$ & 104.54 & 8.58 & 32.40 & 67.18 & 31.00 & 44.41 & 105.30 & 54.05 \\
\hline \multirow[t]{3}{*}{4} & 2013 & Rencana & $28,000.00$ & $21,000.00$ & $15,690.00$ & $15,200.00$ & $11,700.00$ & $11,700.00$ & 710.00 & $14,857.14$ \\
\hline & & Realisasi & $25,683.98$ & $9,399.59$ & $8,055.98$ & $11,976.57$ & 4,153.94 & $3,237.22$ & 631.38 & $9,019.81$ \\
\hline & & $\%$ & 91.73 & 44.76 & 51.34 & 78.79 & 35.50 & 27.67 & 88.93 & 60.71 \\
\hline \multirow[t]{6}{*}{5} & 2014 & Rencana & $28,750.00$ & $22,400.00$ & $17,550.00$ & $15,200,00$ & $11,400.00$ & $11,450.00$ & 750.00 & $15,357.14$ \\
\hline & & Realisasi & $21,786.28$ & $10,767.30$ & $6,724.72$ & $12,081.32$ & $5,522.91$ & $4,144.20$ & 493.35 & $8,788.58$ \\
\hline & & $\%$ & 75.78 & 48.07 & 38.32 & 79.48 & 48.45 & 36.19 & 65.78 & 57.23 \\
\hline & RERATA & Rencana & $30,920.80$ & $21,644.92$ & $15,688.61$ & $14,035.31$ & $10,500.79$ & $10,387.44$ & 838.28 & $14,859.45$ \\
\hline & & Realisasi & $23,829.09$ & $9,192.44$ & $7,011.04$ & $9,277.33$ & $5,233.42$ & $5,087.40$ & 684.03 & $8,616.39$ \\
\hline & & $\%$ & 77.06 & 42.47 & 44.69 & 66.10 & 49.84 & 48.98 & 81.60 & 57.99 \\
\hline
\end{tabular}

Sumber : Data sekunder PT SHS, diolah 
Hampir semua Kantor Regional

cenderung mengalami penurunan

produksi benih bersih padi, kecuali

KR IV. Di KR IV, meskipun

produksi gkp cenderung menurun, tetapi produksi benih bersihnya cenderung naik. Hal ini terjadi, karena adanya perbaikan rendemen benih seperti tercantum pada tabel 3 .

Tabel 3. Rendemen Benih Padi dan Reratanya per KR Selama Lima Tahun (2010-2014)

\begin{tabular}{||c|c|r|r|r|r|r|r|r|r||}
\hline \hline No & Tahun & \multicolumn{1}{|c|}{ KR I } & \multicolumn{1}{c|}{ KR II } & \multicolumn{1}{|c|}{ KR III } & \multicolumn{1}{c|}{ KR IV } & KR V & KR VI & \multicolumn{1}{c|}{ PBS } & RERATA \\
\hline \hline 1 & 2010 & 77.11 & 74.94 & 75.94 & 75.86 & 75.47 & 75.47 & 75.78 & 76.07 \\
2 & 2011 & 76.27 & 75.54 & 71.53 & 74.76 & 76.26 & 75.53 & 76.15 & 75.44 \\
3 & 2012 & 72.86 & 71.70 & 73.36 & 75.77 & 75.51 & 75.56 & 74.45 & 73.83 \\
4 & 2013 & 79.48 & 75.00 & 75.26 & 74.83 & 75.54 & 75.50 & 74.72 & 76.82 \\
5 & 2014 & 75.99 & 76.11 & 75.51 & 76.83 & 75.55 & 75.61 & 75.62 & 76.06 \\
\hline & RERATA & 76.27 & 75.27 & 74.52 & 75.67 & 75.74 & 75.53 & 75.35 & 75.70 \\
\hline \hline
\end{tabular}

Sumber : Data sekunder, diolah

Rendemen benih tidak bergantung

pada banyak sedikitnya calon benih

yang diolah menjadi benih bersih,

tetapi ditentukan oleh kualitas calon

benih yang diolah.

B. Harga Calon Benih Padi (GKP)

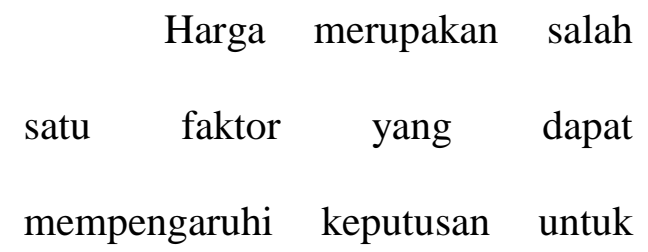

membeli. Harga beli input atau bahan mentah juga dipakai sebagai dasar untuk menentukan harga jual produk jadi.

Dalam kurun lima tahun (2010-2014), rata-rata harga calon benih padi (gkp) selalu mengalami kenaikkan sebagaimana tercantum pada tabel 4 . 
Tabel 4. Harga Pembelian Calon Benih Padi (GKP) per KR Selama Lima Tahun (2010-2014)

$(\mathrm{Rp} / \mathrm{kg})$

\begin{tabular}{||c|c|c|c|c|c|c|c|c|c||}
\hline \hline No & Tahun & KRI & KR II & KR III & KR IV & KR V & KR VI & PBS & RERATA \\
\hline \hline 1 & 2010 & $2,153.52$ & $2,142.22$ & $2,443.85$ & $2,268.08$ & $1,989.94$ & $1,989.94$ & $1,213.30$ & $2,199.31$ \\
2 & 2011 & $2,449.67$ & $2,665.91$ & $2,759.21$ & $2,542.42$ & $2,553.17$ & $2,553.17$ & $1,274.62$ & $2,564.25$ \\
3 & 2012 & $2,537.23$ & $2,739.40$ & $2,747.02$ & $3,058.37$ & $2,697.91$ & $2,422.37$ & $1,363.44$ & $2,666.02$ \\
4 & 2013 & $2,707.26$ & $2,767.62$ & $2,860.50$ & $3,145.37$ & $2,823.71$ & $2,747.01$ & $2,152.92$ & $2,839.14$ \\
5 & 2014 & $3,278.42$ & $3,164.64$ & $3,328.41$ & $3,177.26$ & $3,115.16$ & $2,956.32$ & $1,637.17$ & $3,203.76$ \\
\hline
\end{tabular}

Sumber : Data sekunder, diolah

\section{Keragaan Pabrik Pengolahan}

Benih Padi

Fasilitas pabrik pengolahan

setiap Kantor Regional tidak sama

dari segi jumlah dan kemampuan,

tetapi dari jenis/macamnya hampir fasilitas pabrik pengolahan yang paling banyak dan kapasitasnya paling besar, sedangkan PBS yang paling sedikit dan paling kecil kapasitasnya sebagaimana tampak pada tabel 5. di bawah ini.

sama. Kantor Regional I memiliki

Tabel 5. Keragaan Pabrik Pengolahan Benih Padi per KR Tahun 2010

\begin{tabular}{||l|l|r|r|r|r|r|r|r||}
\hline \hline No & \multicolumn{1}{|c|}{ KERAGAAN } & \multicolumn{1}{c|}{ KR I } & \multicolumn{1}{c|}{ KR II } & KR III & KR IV & KR V & KR VI & PBS \\
\hline \hline 1 & KAPASITAS (ton/th) & 30,000 & 12,500 & 7,500 & 9,000 & 5,500 & 7,500 & 750 \\
2 & BOX DRYER (unit) & 32 & 29 & 18 & 27 & 10 & 10 & 5 \\
3 & LANTAI JEMUR (unit) & 63 & 11 & 5 & 6 & 6 & 6 & 4 \\
4 & UMUR PABRIK (rata-rata th) & 23 & 14 & 23 & 26 & 24 & 29 & 5 \\
5 & TENAGA KERJA (orang) & 45 & 17 & 13 & 12 & 5 & 6 & 4 \\
\hline \hline
\end{tabular}

Sumber : Data sekunder, diolah

Di setiap Kantor Regional terdapat cabang-cabang yang memiliki pabrik pengolahan benih padi. Banyaknya cabang ini tidak sama demikian juga dengan pabrik pengolahan benih padinya. Waktu mulai beroperasinya pabrik pengolahan benih padi juga tidak sama. Dalam hal ini, umur pabrik merupakan rata-rata waktu (tahun) 
pabrik mulai beroperasi dari sejumlah pabrik yang dimiliki masing-masing Kantor Regional.

Tenaga kerja yang

berkaitan langsung dengan aktifitas

pabrik pengolahan benih padi non

hibrida didekati dengan jumlah

pegawai tingkat Kantor Cabang dan

Satgas yang berstatus pegawai tetap

dengan jabatan mulai dari Manajer

Prosesing, Asisten Manajer

Prosesing sampai dengan Petugas

Pengolahan.

\section{Produktivitas Pabrik}

Produktivitas pabrik merupakan rasio antara jumlah produksi benih kantong dengan kapasitas pabrik terpasang. Dalam kurun waktu lima tahun (2010-2014) di PT SHS secara keseluruhan terdapat kecenderungan penurunan produktivitas pabrik benih padi. Pada tingkat Kantor Regional, tingkat produktivitas pabrik benih padi yang paling baik ada di Kantor Regional IV, yaitu di atas 1 sebagaimana dapat dilihat pada tabel 6 .

Tabel 6. Perkembangan Produktifitas Pabrik dan Reratanya per KR Selama Lima Tahun (2010-2014)

\begin{tabular}{||c|c|r|r|r|r|r|r|r|r||}
\hline No & Tahun & \multicolumn{1}{|c|}{ KR I } & \multicolumn{1}{|c|}{ KR II } & \multicolumn{1}{|c|}{ KR III } & \multicolumn{1}{|c|}{ KR IV } & KR V & \multicolumn{1}{|c|}{ KR VI } & \multicolumn{1}{c|}{ PBS } & RERATA \\
\hline \hline 1 & 2010 & 1.18 & 1.09 & 1.15 & 0.84 & 0.91 & 0.91 & 1.04 & 1.02 \\
2 & 2011 & 1.10 & 0.87 & 0.73 & 0.69 & 1.45 & 1.44 & 1.04 & 1.05 \\
3 & 2012 & 0.86 & 0.10 & 0.82 & 0.96 & 0.63 & 0.68 & 0.98 & 0.72 \\
4 & 2013 & 0.86 & 0.75 & 1.07 & 1.33 & 0.76 & 0.43 & 0.84 & 0.86 \\
5 & 2014 & 0.73 & 0.86 & 0.90 & 1.34 & 1.00 & 0.55 & 0.66 & 0.86 \\
\hline & RERATA & 0.95 & 0.74 & 0.93 & 1.03 & 0.95 & 0.80 & 0.91 & 0.90 \\
\hline
\end{tabular}

Sumber : Data sekunder, diolah

Dari hasil produktivitas pabrik pada tabel.6. dan volume pengadaan calon benih padi (gkp) pada tabel 1 . terdapat hubungan logis, yaitu bahwa kecenderungan penurunan volume calon benih padi (gkp) yang diolah akan diikuti oleh penurunan produktivitas pabrik. 


\section{E. Hasil Analisis Regresi}

\section{E.1. Uji Asumsi Klasik}

Salah satu syarat yang harus dipenuhi dalam melakukan analisis regresi adalah data atau variable terbebas dari unsur heteroskedastisitas atau data variable harus homokedastisitas artinya variansinya harus sama. Menurut Gujarati (1978), asumsi penting dalam model regresi linear klasik adalah bahwa variansi

tiap unsur disturbance tergantung pada nilai yang dipilih dari variabel yang

menjelaskan, adalah suatu angka konstan yang sama dengan $\sigma^{2}$. Ini adalah asumsi homokedastisitas yaitu variansi yang sama.
Pada tabel 7. di bawah ini disajikan hasil pengujian untuk mengetahui ada tidaknya unsur heteroskedastisitas pada data atau variabel penelitian. Dari tabel 7. tersebut terlihat bahwa secara simultan variabel bebas tidak signifikan secara statistik. Berarti tidak ada unsur heteroskedastistas. Hal ini ditunjukkan dengan probabilistik nilai $\mathrm{F}$ lebih besar dari taraf signifikansi $\alpha=0,10$. Dari tabel 7. tersebut juga terlihat bahwa tidak ada satupun variabel yang signifikan secara statistik. Hal ini terlihat dari probabilitas nilai $\mathrm{t}$ yang lebih besar dari taraf signifikansi $\alpha=0,10$. Dengan demikian dapat dibuktikan bahwa dalam model tidak terjadi heteroskedastisitas. 
Tabel 5.7. Hasil Uji Heteroskedastisitas pada Penelitian Faktor-Faktor yang Mempengaruhi Produktifitas Pabrik Benih Padi di PT Sang Hyang Seri (Persero)

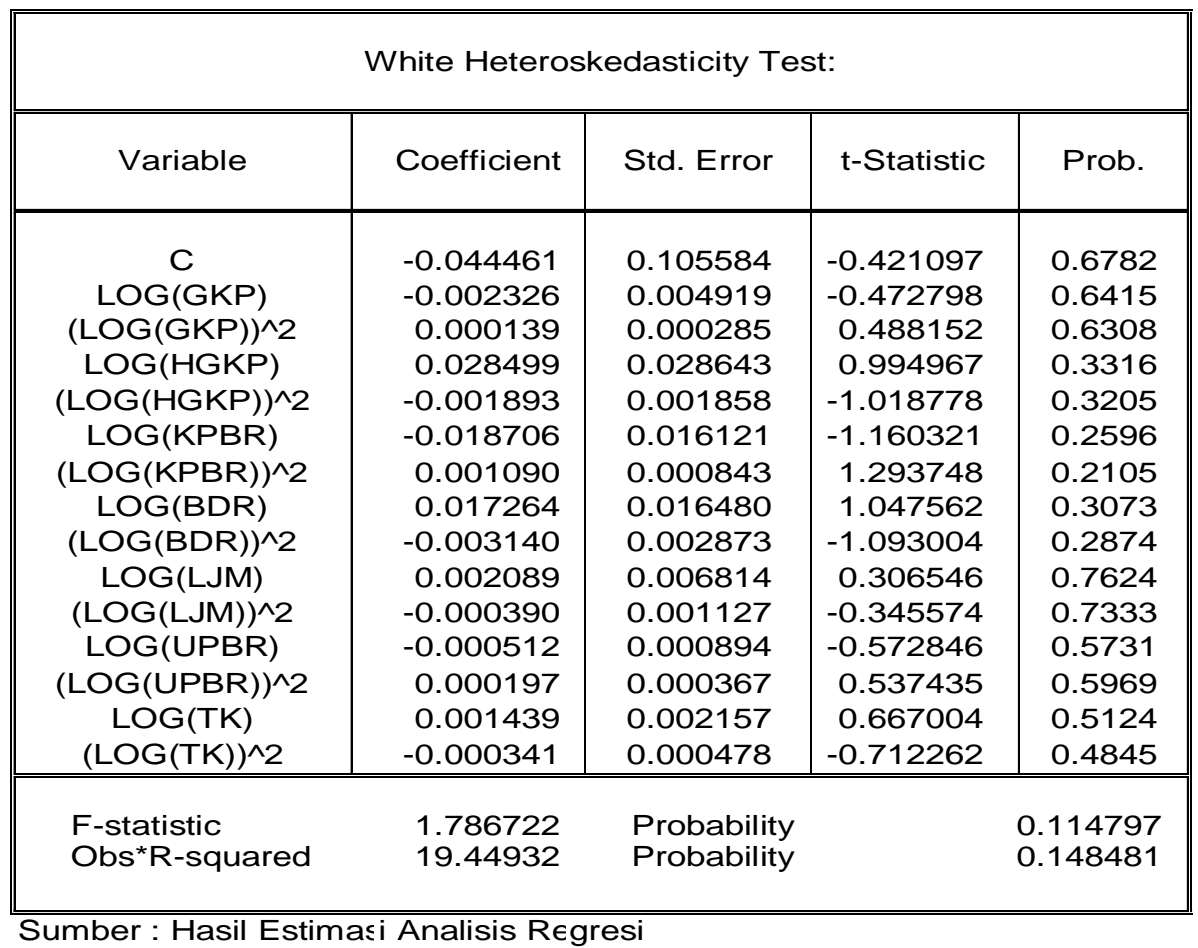

\section{E.2. Uji Kesesuaian Model}

\section{Pada penelitian yang \\ berjudul Faktor-Faktor yang \\ Mempengaruhi Produktivitas Benih}

Padi, beberapa varibel diambil datanya untuk dianalisis. Data yang diambil adalah produksi calon benih padi, harga calon benih padi, kapasitas pabrik, jumlah box dryer, jumlah lantai jemur, umur pabrik (mesin), dan tenaga kerja. Data tersebut dalam model analisis menghasilkan koefisien determinasi $\left(\mathrm{R}^{2}\right)$ sebesar 0,998838 atau koefisien determinasi yang telah disesuaikan (adjusted $\quad \mathrm{R}^{2}$ ) $\quad$ sebesar $\quad 0,998537$ sebagaimana tercantum pada tabel 8 . di bawah ini yang dihitung dengan bantuan program komputer EViews. Hal ini berarti bahwa variabelvariabel tersebut dapat menyebabkan variasi pada produktivitas benih padi 
sebesar $99,88 \quad \% \quad(\quad 99,85 \%)$,

sedangkan $0,12 \%(0,15 \%)$ sisanya

disebabkan oleh variabel di luar model. Dengan demikian pemilihan variabel-variabel tersebut dalam model sudah cukup sesuai.

Tabel 8.Hasil Estimasi Analisis Regresi Faktor-Faktor yang Mempengaruhi Produktivitas Benih Padi di PT Sang Hyang Seri (Persero)

\begin{tabular}{||c|c|l|l|c||}
\hline \multirow{2}{*}{ Variable } & Coefficient & Std. Error & t-Statistic & Prob. \\
\hline \hline C & -0.356374 & 0.180542 & -1.973910 & 0.0587 \\
LOG(GKP) & 1.019438 & 0.007122 & 143.1470 & $0.0000^{\mathrm{a}}$ \\
LOG(HGKP) & 0.011020 & 0.024492 & 0.449941 & 0.6563 \\
LOG(KPBR) & -1.022933 & 0.015461 & -66.16129 & $0.0000^{\mathrm{a}}$ \\
LOG(BDR) & 0.005433 & 0.019211 & 0.282825 & 0.7795 \\
LOG(LJM) & 0.016791 & 0.010318 & 1.627339 & 0.1153 \\
LOG(UPBR) & -0.001189 & 0.010676 & -0.111409 & 0.9121 \\
LOG(TK) & -0.013747 & 0.013073 & -1.051521 & 0.3023 \\
\hline \hline Adjusted R-squared & 0.998537 & S.D. dependent var & 0.453183 \\
S.E. of regression & 0.017332 & Akaike info criterion & -5.074915 \\
Sum squared resid & 0.008111 & Schwarz criterion & -4.719407 \\
Log likelihood & 96.81101 & F-statistic & 3316.928 \\
Durbin-Watson stat & 2.390063 & Prob(F-statistic) & $0.000000^{\mathrm{a}}$ \\
\hline
\end{tabular}

a : Signifikan pada $\alpha=10 \%$

Sumber : Hasil Estimasi Analisis Regresi

\section{E.3. Pengujian Simultan (Uji F)}

$$
\text { Pengujian simultan }
$$

melibatkan keseluruhan variabel

bebas dalam menguji ada tidaknya

pengaruh yang signifikan secara

simultan atau bersama-sama terhadap

variabel tidak bebas. Pengujian secara

simultan mengunakan distribusi $\mathrm{F}$,

yaitu membandingkan antara $F_{\text {hitung }}$

dengan $F$ tabel. Hipotesis yang diajukan $\mathrm{H}_{0}$ adalah semua parameter yang diajukan pada penelitian ini yang meliputi produksi calon benih padi, harga calon benih padi, kapasitas pabrik, jumlah box dryer, jumlah lantai jemur, umur pabrik (mesin), dan tenaga kerja bernilai sama dengan nol yang artinya secara simultan parameter tersebut tidak berpengaruh atau pengaruhnya tidak 
signifikan secara statistik terhadap produktivitas pabrik benih padi. Hipotesis alternatif $\mathrm{H}_{1}$ yang diajukan adalah semua parameter yang diajukan pada penelitian ini yang meliputi produksi calon benih padi, harga calon benih padi, kapasitas pabrik, jumlah box dryer, jumlah lantai jemur, umur pabrik (mesin), dan tenaga kerja bernilai tidak sama dengan nol yang artinya secara simultan parameter tersebut pengaruhnya signifikan secara statistik terhadap produktivitas pabrik benih padi.

Dari tabel 5.8 dapat dilihat hasil pengujian dengan bantuan program komputer Eviews bahwa probabilitas $\mathrm{F}_{\text {statistic }} 0,000$ atau $0,00 \%$ lebih kecil dari taraf signifikansi 10 $\%$. Hal ini berarti bahwa secara simultan atau bersama-sama variabelvariabel tersebut (produksi calon benih padi, harga calon benih padi, kapasitas pabrik, jumlah box dryer, jumlah lantai jemur, umur pabrik (mesin), dan tenaga kerja) mempengaruhi produktivitas pabrik benih padi. Hal ini sama artinya dengan menolak $\mathrm{H}_{0}$ dan menerima $\mathrm{H}_{1}$.

\section{E.4. Pengujian Parsial (Uji t)}

Pengaruh varibel bebas secara individual atau parsial terhadap variabel bergantung dapat pula diukur dengan uji $\mathrm{t}\left(\mathrm{t}_{\mathrm{tes}}\right)$ pada model tersebut. Hipotesis $\mathrm{H}_{\mathrm{o}}$ yang diajukan adalah variabel bebas (produksi calon benih padi, harga calon benih padi, kapasitas pabrik, jumlah box dryer, jumlah lantai jemur, umur pabrik (mesin), dan tenaga kerja) bernilai sama dengan nol yang artinya secara individual parameter tersebut tidak berpengaruh atau pengaruhnya tidak signifikan secara statistik terhadap 
produktivitas pabrik benih padi. Hipotesis $\mathrm{H}_{1}$ yang diajukan adalah produksi calon benih padi, harga calon benih padi, kapasitas pabrik, jumlah box dryer, jumlah lantai jemur, umur pabrik (mesin), dan tenaga kerja masing-masing bernilai tidak sama dengan nol yang artinya secara individual parameter tersebut pengaruhnya signifikan secara statistik terhadap produktivitas pabrik benih padi.

Hasil uji t masing-masing variabel penelitian yang meliputi produksi calon benih padi, harga calon benih padi, kapasitas pabrik, jumlah box dryer, jumlah lantai jemur, umur pabrik (mesin), dan tenaga kerja yang diuji dengan bantuan program komputer Eviews disajikan pada tabel 5.8. Hasil uji t yang signifikan secara statistik ditunjukkan oleh angka probabilitas sebesar 0.0000 atau $0,00 \%$ yang lebih kecil dari taraf signifikansi 10 $\%$. Dari variabel bebas dalam model penelitian yang memberi pengaruh signifikan secara statisik terhadap produktivitas pabrik benih padi adalah produksi calon benih padi (GKP) dan kapasitas pabrik (KPBR).

\section{a. Produksi calon benih padi (GKP)}

Hasi uji $\mathrm{t}$ menyatakan bahwa variabel produksi calon benih padi berpengaruh signifikan secara statistik terhadap produktivitas pabrik benih padi dengan angka koefisien variabel $\left(b_{1}\right) \quad 1.019438$ artinya tiap satu persen peningkatan produksi calon benih padi yang diolah akan meningkatkan produktivitas calon benih padi sebesar $1.019438 \%$. 


\section{b. Harga calon benih padi (HGKP)}

Hasil uji $\mathrm{t}$ menyatakan bahwa variabel harga calon benih padi tidak signifikan secara statistik mempengaruhi produktivitas pabrik benih padi. Hal ini dapat terjadi, karena PT SHS tetap akan memproduksi benih padi yang tiap tahun targetnya selalu naik dengan membeli calon benih padi berapapun tingkat harga calon benih padi yang terjadi. Tanda koefisien regresi harga calon benih padi yang positif dapat menjelaskan perilaku tersebut walaupun tidak berbeda nyata.

\section{c. Kapasitas Pabrik (KPBR)}

Hasi uji $t$ menyatakan bahwa variabel kapasitas pabrik berpengaruh signifikan secara statistik terhadap produktivitas pabrik benih padi dengan angka koefisien variabel $\quad-1.022933$, artinya jika kapasitas pabrik ditingkatkan sebesar satu persen maka justru terjadi penurunan produktivitas pabrik benih padi sebesar $-1.022933 \%$. Hal ini dapat terjadi, karena pada saat ini kapasitas pabrik benih tidak secara optimal dimanfaatkan. Tingkat produktivitas pabrik benih padi lebih kecil daripada satu (tabel 5.6). Jadi, jika pada saat ini saja kapasitas terpasang pabrik benih padi tidak dapat dipenuhi, maka apabila kapasitas pabrik ditingkatkan akibatnya produktivitas pabrik akan turun selama faktor-faktor lain tidak ada perubahan.

\section{d. Box dryer (BDR)}

Hasil uji $\mathrm{t}$ menyatakan bahwa variabel box dryer tidak signifikan secara statistik mempengaruhi produktivitas pabrik benih padi. 
Hal ini terjadi, karena jumlah box dryer yang dipunyai PT SHS tidak beroperasi secara penuh. Dari tanda koefisien regresi box dryer yang positif patut diduga bahwa sebenarnya penambahan jumlah box dryer tersebut mempunyai potensi untuk meningkatkan kapasitas pabrik benih padi.

\section{e. Lantai Jemur (L JM)}

Hasil uji $t$ menyatakan bahwa variabel lantai jemur tidak signifikan secara statistik mempengaruhi produktivitas pabrik benih padi. Hal ini terjadi, karena lantai jemur yang dipunyai PT SHS tidak berfungsi secara penuh. Dari tanda koefisien regresi lantai jemur yang positif patut diduga juga bahwa sebenarnya penambahan jumlah lantai jemur tersebut mempunyai potensi untuk meningkatkan kapasitas pabrik benih padi.

\section{f. Umur pabrik (mesin) (UPBR)}

Hasil uji t menyatakan bahwa variabel umur pabrik (mesin) benih padi tidak signifikan secara statistik mempengaruhi produktivitas pabrik benih padi. Hal ini terjadi, karena perbaikan dan pemeliharaan terhadap mesinmesin pengolahan yang ada masih cukup mampu membuat kinerja mesin-mesin tersebut tetap baik. Tanda koefisien regresi umur pabrik negatif dapat member informasi kepada PT SHS bahwa umur mesin yang semakin tua akan cenderung menurunkan produktivitas pabrik benih padi.

\section{g. Tenaga kerja (TK)}

Hasil uji t menyatakan bahwa
variabel tenaga kerja tidak
signifikan secara statistik


mempengaruhi produktivitas pabrik benih padi. Keadaan ini terjadi karena jumlah tenaga kerja yang ada masih mampu (cukup) untuk menangani jumlah calon benih yang diolah baik secara manual maupun menggunakan mesin atau peralatan. Tanda koefisien regresi tenaga kerja negatif dapat mengindikasikan bahwa tenaga kerja yang langsung menangani kegiatan pabrik (pengolahan benih) saat ini tidak perlu ditambah karena fasilitas pengolahan benih yang dipunyai PT SHS tidak bekerja secara optimal. Tanda negatif tersebut barangkali juga dapat diartikan bahwa produktivitas pabrik benih padi dapat meningkat jika jumlah tenaga kerja yang langsung terlibat kegiatan pengolahan benih dikurangi. Implikasinya, ditengarahi bahwa tenaga kerja yang ada saat ini banyak yang memiliki waktu luang.

\section{h. Konstanta $\left(b_{0}\right)$}

Intersep atau konstanta

$\left(b_{0}\right) \quad$ sebesar -0.356374 artinya produktivitas pabrik benih padi akan menurun atau berkurang sebesar $-0.356374 \%$ tanpa adanya pengaruh dari faktor-faktor dalam model penelitian yang meliputi produksi calon benih padi, harga calon benih padi, kapasitas pabrik, jumlah box dryer, jumlah lantai jemur, umur pabrik (mesin), dan tenaga kerja.

Berdasarkan besaran konstanta dan koefisien regresi, maka model penelitian dengan judul Faktor-Faktor yang Mempengaruhi Produktivitas Pabrik Benih Padi PT Sang Hyang 
Seri (Persero) dapat ditulis sebagai

berikut :

$\ln$ PROVITAS $=-0.356374+1.019438$

$\operatorname{lnGKP}+0.011020 \operatorname{lnHGKP}-1.022933$

$\ln \mathrm{KPBR}+(-1.973910)(143.1470)^{\mathrm{a}}$

$(0.449941)(-66.16129)^{\mathrm{a}} 0.005433 \ln$ BDR

$+0.016791 \ln$ LJM - $0.001189 \ln$ UPBR

- $0.013747 \ln$ TK $(0.282825)$

(1.627339)(-0.111409) (-1.051521)

\section{KESIMPULAN DAN SARAN}

\section{A. KESIMPULAN}

Berdasarkan hasil penelitian dan pembahasan terdapat beberapa kesimpulan sebagai berikut :

1. Rata-rata pengadaan calon benih padi (gkp) dalam kurun waktu lima tahun (2010-2014) di PT SHS secara keseluruhan cenderun menurun. Dengan adanya kecenderungan penurunan produksi gkp, maka produksi benih bersih padi (BB) juga cenderung menurun. Penurunan produksi gkp yang mengakibatkan penurunan produksi benih bersih dapat mengurangi produktivitas pabrik benih padi.

2. Dalam kurun lima tahun (20102014), rata-rata harga calon benih padi (gkp) selalu mengalami kenaikkan. Harga calon benih padi (gkp) yang selalu naik tersebut tidak selalu diikuti dengan pengurangan produksi gkp. Pada dasarnya, target produksi benih padi PT SHS selalu mengalami kenaikkan mengikuti RKAPnya.

3. Dari segi fasilitas pabrik untuk mendukung produksi benih padi, terdapat perbedaan jumlah untuk setiap Kantor Regional, sehingga menentukan kapasitas pabrik dan target produksinya.

4. Produktivitas pabrik benih padi rata-rata (2010-2014) PT SHS cenderung menurun. Tingkat produktivitasnya di bawah $1(<1)$ 
yang berarti produksi benih padinya di bawah kapasitas terpasangnya. Hal ini bersesuaian dengan terjadinya penurunan produksi calon benih padi (gkp) dan produksi benih bersih (BB) padi pada kurun waktu yang sama.

5. Model yang digunakan dalam menaksir produktivitas pabrik benih padi sudah cukup baik. Hal ini dapat dilihat bahwa data atau variabel yang dimasukkan dalam model terbebas dari unsur heteroskedstisitas. Nilai koefisien determinasi $\quad\left(\mathrm{R}^{2}\right) \quad$ sebesar 0,998838 atau adjusted $\mathbf{R}^{2}$ sebesar 0,998537 yang berarti bahwa $99,88 \%$ atau $99,85 \%$ variasi produktivitas pabrik benih padi dapat dijelaskan oleh variabel-variabel produksi calon benih padi, harga calon benih padi, kapasitas pabrik, jumlah box dryer, jumlah lantai jemur, umur pabrik (mesin), dan tenaga kerja.

6. Dari hasil estimasi dapat dinyatakan bahwa secara bersama-sama variabel-variabel produksi calon benih padi, harga calon benih padi, kapasitas pabrik, jumlah box dryer, jumlah lantai jemur, umur pabrik (mesin), dan tenaga kerja berpengaruh nyata secara statistik terhadap produktivitas pabrik benih padi.

7. Dari hasil estimasi dapat dinyatakan pula bahwa secara individual terdapat 2 (dua) variabel bebas yang memberi pengaruh signifikan secara statistik terhadap produktivitas pabrik benih padi ( $\alpha=10 \%$ ), yaitu produksi calon benih padi 
(gkp) dan kapasitas pabrik.

Produksi calon benih padi (gkp) berpengaruh positif, sedangkan kapasitas pabrik berpengaruh negatif.

\section{B. SARAN}

Merujuk pada pembahasan hasil penelitian dan kesimpulan di atas, maka penulis mengajukan beberapa saran yang dapat dipergunakan sebagai implikasi kebijakan sebagai berikut :

1. Pada saat penelitian ini produktivitas pabrik benih padi PT SHS belum optimal dan ada kecenderungan terus menurun. Oleh karena itu, perlu diambil langkah-langkah tertentu untuk mengoptimalkan kapasitas pabrik, antara lain dengan peningkatan pengadaan atau pembelian calon benih padi (gkp) sedemikian sehingga produksi benih bersihnya minimal sampai pada kapasitas terpasangnya. Pemanfaatan box dryer dan lantai jemur juga perlu ditingkatkan.

2. Umur pabrik (mesin) sudah cukup tua. Perawatan dan perbaikan mesin yang telah dilaksanakan selama ini cukup membantu kinerja mesin. Namun demikian, mesin yang sudah tua tersebut secara bertahap perlu segera diganti (diperbaharui), karena terdapat indikasi bahwa pada tahun-tahun mendatang mesin yang sudah tua tersebut jika tidak diganti akan menurunkan produktivitas pabrik benih padi.

3. Dengan adanya indikasi bahwa tenaga kerja masih memiliki waktu luang dalam satu hari kerja normal, maka perlu pengendalian dan pengawasan 
jam kerja oleh bagian

sumberdaya manusia atau atasan

langsung petugas agar waktu

luang dapat dikonversikan untuk

kegiatan yang produktif.

4. Sebagaimana

koefisien

determinasi $\left(\mathrm{R}^{2}\right)$ hasil estimasi

yang belum menyentuh angka

$100 \%$, maka berarti masih

terdapat faktor-faktor lain di luar

model yang belum dimasukkan

dalam analisis. Oleh karena itu,

penelitian ini perlu dilanjutkan

untuk dapat mengidentifikasi

lebih lanjut faktor-faktor lain

yang dapat mempengaruhi

produktivitas pabrik benih padi.

\section{DAFTAR PUSTAKA}

Cahyono, Bambang. 1996. Manajemen Sumber Daya Manusia. Jakarta: Badan Penerbit IPWI.

Fakultas Pasca Sarjana UGM. 1991. Pedoman Penulisan Disertasi. Pasca Sarjana UGM. Yogyakarta
Gaspersz, Vincent, 2000. "Manajemen Produktivitas Total : Strategi Peningkatan Produktivitas Bisnis Global, PT. Gramedia Pustaka Umum, Jakarta.

Hadi, Sutrisno. 2000. Metodologi Research. Andi. Yogyakarta.

Juliani, Irma. 2005. Analisis Faktor-Faktor Yang Mempengaruhi Produksi Tandan Buah Segar Kelapa Sawit Pada PT Sewangi Sejati Luhur, Riau. Tesis. Program Studi Magister Manajemen Agribisnis. Sekolah Pasca Sarjana Universitas Gadjah Mada Yogyakarta.

Karjadi, Mintaroem. 2003. Analisis Faktorfaktor Yang Mempengaruhi Pertumbuhan

Industri Kecil Di Wilayah Scgitiga Industri Di Jawa Timur (Surabaya, Sidoarjo

dan Gresik). Majalah Ekonomi. Tahun XIII. No 2.

Muhidin, Sambas Ali dan Maman Abdurahman. 2011. Analisis Korelasi, Regresi, dan Jalur dalam Penelitian. CV Pustaka setia. Bandung.

Mutiara, Ayu. (2010). Analisis Pengaruh Bahan Baku, Bahan Bakar dan Tenaga Kerja Terhadap Produksi Tempe di Kota Semarang (Studi Kasus di Kelurahan Krobokan). Skripsi. Fakultas Ilmu Ekonomi dan Studi pembangunan, Universitas Diponegoro, Semarang.

Nazir, Moh. 2003. Metodologi Penelitian. Ghalia Indonesia. Jakarta

Nuswardhani, 2011. Pengaruh Kemampuan dan Motivasi terhadap Kinerja 
Karyawan PT SHS (Persero) KR III. Yogyakarta

Pallant,Julie, 2007. SPSS Survival Manual: A Step by Step Guide to Data Analysis using SPSS for Windows, Third Edition (Berkshire: McGraw-Hill and Open UniversityPress.

Pujotomo, Darminto dan kawan-kawan, 2008. Analisis Pengukuran Produktivitas Pada Cv. Citra Jepara Furniture. Jurnal J@TI Undip, Vol III, No 1, Januari 2008. Program Studi Teknik Industri Universitas Diponegoro, Semarang

Rahmawati, Rika. 2006. Analisis FaktorFaktor Yang Mempengaruhi Produktivitas Perusahaan (Suatu Kasus Pada Perusahaan Jasa Pelaksana Konstruksi PT MATRIX PRIMATAMA Bandung), Program Pendidikan Ekonomi Dan Koperasi, Jurusan Pendidikan Ekonomi, Fakultas Pendidikan Ilmu Pengetahuan Sosial, Universitas Pendidikan Indonesia.

Ravianto, J., 1986. Produktivitas dan Pengukuran. Lembaga Sarana Informasi Usaha dan Produktivitas. Jakarta.

Ramadhani, Yuliastuti. 2011. Analisis Efisiensi, Skala dan Elastisitas Produksi Dengan

Pendekatan Cobb-Douglas dan Regresi Berganda. Jurnal Teknologi, Volume 4 Nomor 1, Juni 2011, 61-53. Teknik Industri. Fakultas Teknologi industri institut Sains \& Teknologi AKPRIND, Yogyakarta.

Sang Hyang Seri (Persero), PT. 2010.Company Profile. Jakarta.
Sang Hyang Seri (Persero), PT. 2011. Desain Produk Benih 2011. Jakarta.

Sang Hyang Seri (Persero), PT. 20062010.Laporan Tahunan. Jakarta.

Satriawan, I Ketut, 1987. Pengukuran dan Perencanaan Produktivitas Pabrik Minyak Kelapa Sawit Perkebunan Bekri PT Perkebunan X (Persero) Lampung. Fakultas Teknologi Pertanian, Institut Pertanian Bogor. Bogor.

Sedarmayanti. 2009. Tata Kerja dan Produktivitas Kerja. CV. Mandar Maju, Bandung.

Sink, D. Scott., (1985), Productivity Management : Planning, Measurement and Evaluation, Control and Improvement. New York : John Wiley $\&$ Sons.

Sinungan, Muchdarsyah. 2009. Produktivitas : Apa dan Bagaimana. Bumi Aksara. Jakarta.

Sukardi dan Wahyu Gumilar, 2008. Kajian Kapasitas Lini Pengolahan Industri Teh Hitam Ortodoks di PT Perkebunan Nusantara VIII Kebun Pasir Nangka, Cianjur. Departemen Teknologi Industri Pertanian. Fakultas Teknologi Pertanian. Institut Pertanian Bogor.

Summanth, D.J. (1985). Productivity Engineering and Management. McGraw-Hill. New York.

Sunyoto, Danang. 2008. Analisis Regresi dan Uji Hipotesis. MedPress. Yogyakarta.

Surakhmad, Winarno. 1998. Pengantar Penelitian Ilmiah. Tarsito. Bandung 
Susila, Wayan R, dan Bonar M. Sinaga. 2005. Analisis Kebijakan Industri Gula Indonesia. Jurnal Agro Ekonomi. Volume 23 No.1, Mei 2005: 30-53

Universitas Gadjah Mada. 1997. Petunjuk Penulisan Usulan Penelitian dan Tesis. Program Pasca-sarjana Universitas Gadjab Mada, Yogyakarta 